TOMISLAV JOSIP MLINARIĆ, Ph.D.

E-mail: mlinaric@fpz.hr

University of Zagreb,

Faculty of Transport and Traffic Sciences

Vukelićeva 4, HR-10000 Zagreb, Republic of Croatia

MIRAN PIRNAR, B. Eng.

E-mail:miran.pirnar@slo-zeleznice.si

Slovenske železnice d.o.o.

Kolodvorska ul. 11, SI-1506 Ljubljana, Republic of Slovenia
Traffic Infrastructure

Preliminary Communication

Accepted: Dec. 23, 2008

Approved: Mar. 11, 2009

\title{
OPTIMIZING TRACK INFRASTRUCTURE AVAILABILITY
}

\begin{abstract}
Failure to realize the schedule which is primarily reflected in train delays is the direct consequence of insufficient availability of capacities of the current railway infrastructure which are generated by low level of usable quality of the track network in general. The aim of the research presented in this paper is to determine the method of optimal interventions of the rail infrastructure managers and traffic control activities on the reduction of the influence of slow runs and line closures thus ensuring a sufficient number of rail routes for the customers' needs and consequently higher quality realization of the schedule. The paper gives a concrete presentation of the volume of slow runs and line closures, calculation of reducing the level of railway capacities with a simulation and the result of this condition on the capacity of the concrete railway line and the proposal of a model for organizing an expert group within the traffic control activities for the fastest possible elimination of these negative phenomena.
\end{abstract}

\section{KEY WORDS}

liberalization, route leasing, quality deterioration, track availability

\section{INTRODUCTION}

In the European area the introduction of liberalization on the railway transport market in the railways operation has brought to deep and basic changes both in the organizational and in the technical and technological segment. The basic strategic goal of regulated use $^{1}$ of the railway infrastructure is to provide all the national and private railway operators with a simple and non-discriminating approach to technically and technologically integrated European rail network allowing thus equal conditions to all the competitors on the rail transport market.

The realization of such concept for the rail infrastructure manager in the operative sense means first of all provision of the maximally simple access to the rail infrastructure. The basic precondition to achieve this goal is the satisfactory level of the availability of rail infrastructure capacities / routes that insure the necessary level of service quality and prevent sloppiness and irregularity in rail passenger and freight traffic to rail operators and transport organizers.

In order to fulfil the basic precondition the key question refers to the usage level of the rail infrastructure. Since from the technical and technological aspect the track infrastructure maintenance system ensures the track availability according to the pre-determined standard the basic issue is the provision of high-quality management system (supervision, control and planning) by maintenance and reconstruction of the track infrastructure. Finally, every management improvement through maintenance and reconstruction of the track infrastructure, based on the pre-defined maintenance tasks, will result in actual, positive effect on its availability and eventually on the realized revenue.

This paper presents the results of previous studies carried out by the author in this field which contribute significantly both to the theory of track geometry quality deterioration and the significant improvement of the past practice in the track maintenance system which is crucial for the optimization of the track infrastructure capacity availability.

The past approach and considerations of the majority of authors regarding the analysis of the track quality deterioration was individual. The individual deterioration of single track parameters, namely, was studied individually, with the set criterion of how well and precise each single one of them explains the change in the quality of the track geometry. Individual deterioration relations are initially calibrated by using the statistical analysis of "multiple linear regression". The past results based also on the author's research (significantly change the current approach to the observed problems), obtained by studying the development of the track geometry quality in relation to the traffic and time [2], in the areas of different railway administrations (the authors carried out research ${ }^{2}$ for 
the needs of OEBB, SŽ and HŽ) can be expressed in the following way:

1. Original quality conditions of traffic operation per track that were achieved at the moment when the construction was completed and it was opened to traffic, cannot be achieved again through usual type of maintenance;

2. The best possible qualitative conditions of traffic operation per track that can be achieved in a certain time period are directly related to the running cycles and track maintenance cycles.

3. The interval between the track maintenance cycles is reduced with the increase in traffic and increase of the total number of track maintenance cycles within a certain period of time.

If the track infrastructure maintenance system does not recognize such approach to understanding of the quality deterioration process of the track geometry this becomes the biggest barrier in the schedule realization. It is reflected first of all in the elimination of a certain number of the already agreed routes due to the introduction of slow runs and line closures that could have been avoided on time. Therefore, one of the priority goals, both strategic and operative ones, of the track infrastructure maintenance activities and the traffic control activities is to eliminate slow runs and reduce line closures to a minimum.

Such an efficient system [3] requires top qualified employees and provision of sufficient material means not only for the current year but at least for a mid-term period of a minimum of 5 years. Those responsible for railway line maintenance carry out engineering maintenance realization cycles within a precisely determined environment (Figure 1).

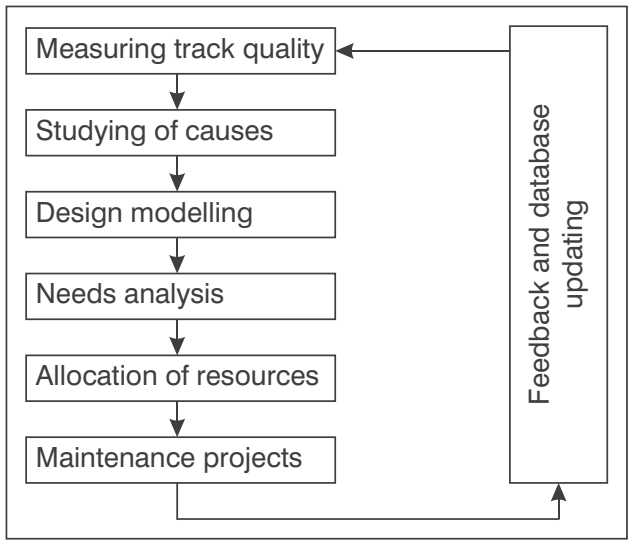

Figure 1 - Realization cycle of the engineering maintenance tasks

The realization of these tasks requires also the knowledge about complex interactions between the condition and behaviour of the track structure and the influence of the performed maintenance and reconstruction on the track exploitation quality.

\section{ANALYSIS OF CONSEQUENCES OF THE TECHNOLOGICALLY INEFFI- CIENT TRACK INFRASTRUCTURE MAINTENANCE SYSTEM}

Both the Croatian and Slovenian railway systems have adopted the national quality management processes whose aim is service quality assurance, accompanied by continuous improvement of rail system efficiency by implementing the procedures that reduce the irregularities in rail passenger and freight traffic. The basis of high-quality and efficient infrastructure capacity management lies in the safe and reliable train traffic, which is presented by high-quality database which registers the operation of all the trains (Figure 2 and Table 1 - source SŽ).

The rail infrastructure managers have to collect data on the reliability of performing rail traffic of passenger and freight trains according to pre-accepted and published schedule. The part of the schedule which refers to trains in international traffic is realized according to harmonized procedures and methods.

The regularity of trains is determined at agreed measuring positions passed by the running train, based on the possible deviations between the planned schedule and the actual train travelling times (realized schedule) expressed in minutes. The agreed measuring positions of train travelling are in fact positions related to the technology of operation (arranged stations, dispatch stations, interstations and terminal stations with their technical and technological characteristics), which are defined as points passed by every single train.

The punctuality of trains is one of the most important qualitative parameters of the service quality level of rail transport. All the reasons for delays are classified according to UIC Directive 450-.

Efficiency quality assurance is in fact an issue of long-term design of track infrastructure capacities which is to result in the realization of the schedules with minimal level of conflicts. This process has to be consistent, since otherwise it will cause disturbances in traffic, big train delays and additional substantial costs.

The presented analysis indicates the big influence of the construction reasons (Figure 2) on the level of the quality of availability and the track infrastructure use. In this context, for the long-term design of the track infrastructure capacities it is necessary to explain and determine the phenomenon of the pure track geometry deterioration for the observed past period of time $^{2}$ (which is as a rule expressed by the quality index in time (t) $-\mathrm{MDZ}^{2}$ ), as well as for the observed track geometry quality improvement achieved by the determined realized maintenance and repair of track infrastructure. 


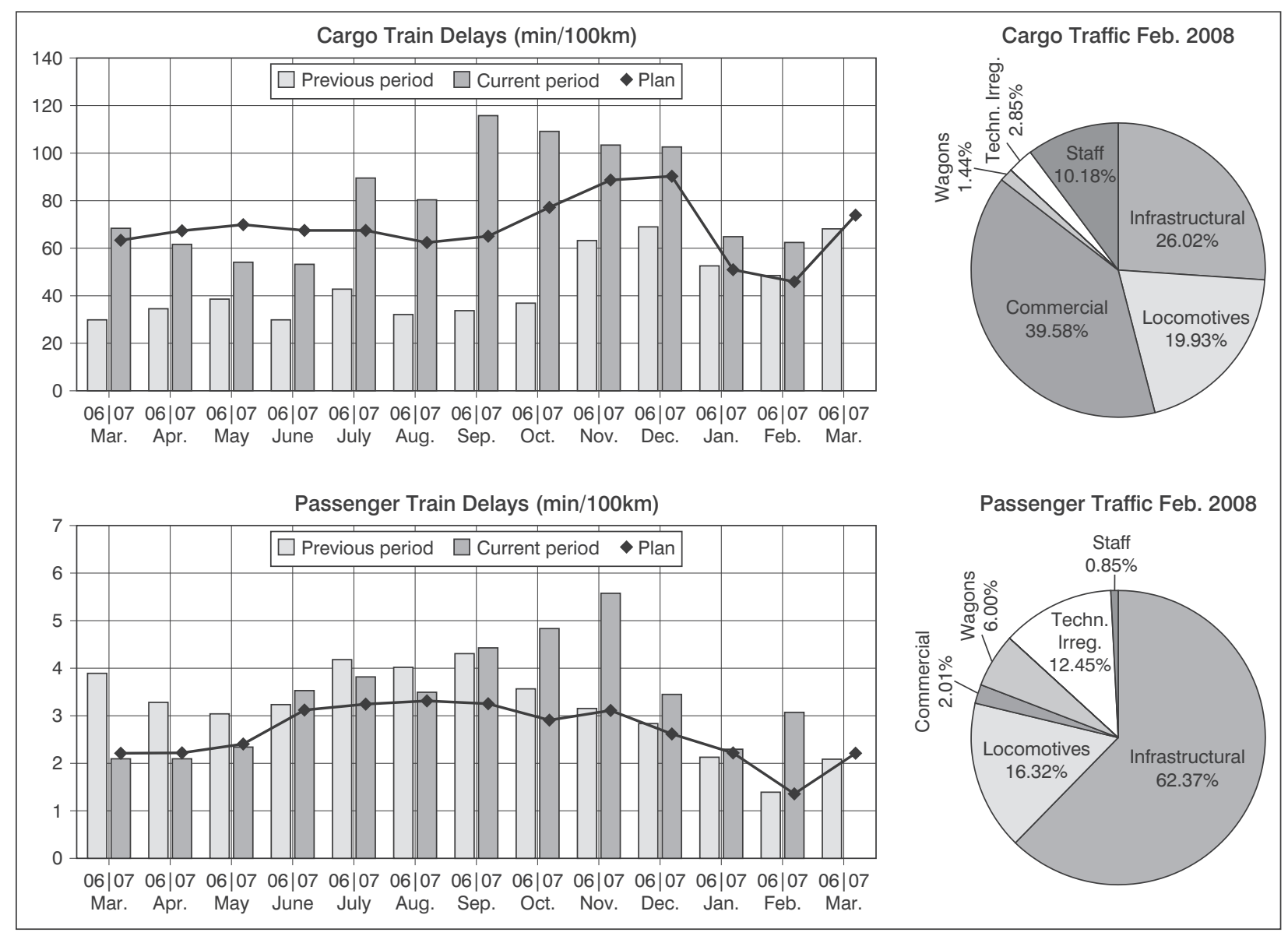

Figure 2 - Overview of train delays according to delay causes

Table 1 - Introduced slow runs due to construction reasons and prolongation of travelling hours

\begin{tabular}{|c|c|c|c|c|c|c|c|c|c|c|c|}
\hline Date & Train & Dep. & Med & Station & $\begin{array}{l}\text { Contr. } \\
\text { point }\end{array}$ & Sect. & Code & $\begin{array}{l}\text { Train } \\
\text { type }\end{array}$ & Cause & Section & Hour/Terminal \\
\hline 0312 & 41401 & & 4 & 43400 & 43400 & 31 & 31 & A & $\begin{array}{c}\text { delay because of slow run } \\
\text { (inform. with order, at signal) }\end{array}$ & Maribor-Šentilj & $0803120820 / 2214$ \\
\hline 0312 & 41407 & & 2 & 43400 & 43400 & 31 & 31 & A & $\begin{array}{c}\text { delay because of slow run } \\
\text { (inform. with order, at signal) }\end{array}$ & Maribor-Šentilj & $0803121554 / 2214$ \\
\hline 0312 & 41701 & & 11 & 42300 & 42300 & 50 & 31 & A & $\begin{array}{c}\text { delay because of slow run } \\
\text { (inform. with order, at signal) }\end{array}$ & $\begin{array}{l}\text { Ljubljana- } \\
\text { Borovnica }\end{array}$ & $0803130143 / 2564$ \\
\hline 0312 & 41701 & & 1 & 42207 & 42207 & 04 & 31 & A & $\begin{array}{c}\text { delay because of slow run } \\
\text { (inform. with order, at signal) }\end{array}$ & $\begin{array}{l}\text { Zidani Most - } \\
\text { Zalog }\end{array}$ & $0803130312 / 410$ \\
\hline 0312 & 41704 & & 1 & 42300 & 42300 & 05 & 31 & A & $\begin{array}{c}\text { delay because of slow run } \\
\text { (inform. with order, at signal) }\end{array}$ & $\begin{array}{c}\text { Zalog - } \\
\text { Ljubljana }\end{array}$ & $0803122017 / 410$ \\
\hline 0312 & 41704 & & 13 & 44500 & 44500 & 55 & 31 & A & $\begin{array}{c}\text { delay because of slow run } \\
\text { (inform. with order, at signal) }\end{array}$ & Divača-Sežana & $0803122256 / 2564$ \\
\hline 0312 & 41902 & & 19 & 42300 & 42300 & 50 & 31 & A & $\begin{array}{c}\text { delay because of slow run } \\
\text { (inform. with order, at signal) }\end{array}$ & $\begin{array}{l}\text { Ljubljana- } \\
\text { Borovnica }\end{array}$ & $0803130042 / 2564$ \\
\hline 0312 & 41902 & & 1 & 42207 & 42207 & 04 & 31 & A & $\begin{array}{c}\text { delay because of slow run } \\
\text { (inform. with order, at signal) }\end{array}$ & $\begin{array}{l}\text { Zidani Most - } \\
\text { Zalog }\end{array}$ & $0803130241 / 410$ \\
\hline 0312 & 41902 & & 1 & 42200 & 42200 & 04 & 31 & A & $\begin{array}{c}\text { delay because of slow run } \\
\text { (inform. with order, at signal) }\end{array}$ & $\begin{array}{l}\text { Zidani Most - } \\
\text { Zalog }\end{array}$ & $0803130242 / 410$ \\
\hline 0312 & 41910 & & 11 & 42300 & 42300 & 50 & 31 & A & $\begin{array}{c}\text { delay because of slow run } \\
\text { (inform. with order, at signal) }\end{array}$ & $\begin{array}{l}\text { Ljubljana- } \\
\text { Borovnica }\end{array}$ & $0803121935 / 2564$ \\
\hline 0312 & 41910 & & 1 & 42207 & 42207 & 04 & 31 & A & $\begin{array}{c}\text { delay because of slow run } \\
\text { (inform. with order, at signal) }\end{array}$ & $\begin{array}{l}\text { Zidani Most - } \\
\quad \text { Zalog }\end{array}$ & $0803122039 / 410$ \\
\hline
\end{tabular}




\section{THEORETICAL CONSIDERATIONS FOR OPTIMIZING THE AVAILABILITY OF TRACK INFRASTRUCTURE CAPACITY}

Precise determining of the capacity of single railway lines in the rail track network [1] is the basis for high-quality supply of the railway transport services. On railway lines in exploitation the line capacity is determined based on the train traffic graph. In designing of new railway lines the capacity is determined analytically according to the critical interstation distance.

Theoretically, the railway line capacity ${ }^{3}$ is the capability of the respective limiting distance to let through a certain number of trains or train pairs within a certain period of time, taking into consideration its technical equipment, respective traction vehicles and the existing organization of train operation. The number of train pairs (freight) that pass along the railway line during 24 hours, provided there is parallel train operation graph, is called maximal theoretical capacity of a single track railway line. In case of double track railway lines the capacity is expressed by the number of trains that can pass along the railway line within 24 hours in both directions ${ }^{4}$.

The train travel times on inter-station distance along the line are not the same, and the railway line capacity needs to be determined according to that inter-station distance on which the travelling time for a pair of trains is the longest. This distance is called critical (limited) inter-station distance. Maximal single track railway line capacity in parallel operation graph is determined according to the following formula:

$$
n_{\max }=\frac{1440}{T_{g}}\left[\frac{\text { trains }}{24 \text { hours }}\right]
$$

where:

$\mathrm{n}_{\max }-$ maximal number of pairs of trains within 24 hours,

$\mathrm{T}_{\mathrm{g}}$ - graph period [min].

In non-parallel operation graphs, maximal capacity is calculated for the dominating train categories, usually for freight trains, according to formula:

$$
n_{t}=\frac{n_{\max }}{1+p}-\delta^{*} n_{p}
$$

where:

$\mathrm{n}_{\max }$ - maximal capacity according to parallel graph,

$\mathrm{p}$ - reserve coefficient

- for single track railway line $\mathrm{p}=4 / 24=0.17$

- for double track railway line $\mathrm{p}=3 / 24=0.125$,

$\delta$ - coefficient of cancellations,

$n_{p}-$ number of passenger train pairs per day.
The coefficient of cancellations ${ }^{5}$ indicates how many pairs of trains from the parallel graph cancel a pair of trains of a higher category. The railway line operation has to foresee i. e. provide a time for overhaul and current maintenance which reduces the capacity. In case of single track railway lines this is four hours and in double track railway lines three hours daily. According to the above adopted time for overhaul and current maintenance a reserve is taken, $17 \%$ for single track railway lines, and $12.5 \%$ for double track railway lines.

An important improvement that would completely change the previous understanding of the available track infrastructure capacity is to determine and prove the correlation between the reserve coefficient (p) and the function of track geometry deterioration including the function of its possible improvement at the given moment by the existing practice of maintenance and reconstruction [6,7]. Then the reserve coefficient can be observed not as a constant any more but rather as a variable value whose change in time is directly related to the condition of the track geometry quality.

The theoretical considerations that are necessary in order to explain in detail this influence and which follow the idea that the reserve coefficient $(p)$ is treated as time-changeable value, are based on the studies carried out at the "Institut fuer Eisenbahnwesen", TU Graz ${ }^{2}$. Thus, the key issue of this research in the context of improving i. e. optimizing the availability of the track infrastructure capacity is the determination of the relation between $(\mathrm{p})$ and the deterioration rate of the track geometry quality $\mathrm{dQ} / \mathrm{dt}$.

This research has proven first of all that the track geometry deterioration is best described by the exponential function [4], and it was determined also which form of exponential function best describes the observed behaviour of the quality index ${ }^{7}$. It was also determined that the deterioration rate of the obtained function approximations was higher the lower the total quality of track parameters of the studied track sections. This is in accordance with the set initial hypotheses that depending on the periods of time within which the track geometry deterioration is observed, it features three phases: 1) linear track geometry deterioration with initial increase in the traffic on the track; 2) linear trend of track geometry deterioration in a certain period of time and/or at a constant track operation increase rate, immediately following the initial phase of the deterioration process; 3 ) non-linear trend of rapid track geometry deterioration following the moment of reaching the critical conditions of track exploitation (Figure 3).

The second part of research determines the relation between the existing track geometry quality and possible improvement of this condition [5] by the existing maintenance and reconstruction practice (Fig- 
ure 4). Regarding the second part of the analysis in which the improvement of the track geometry achieved by the set realized maintanence ${ }^{2}$ has been studied, it should be said that the following facts have been determined:

1) the values of the quality index of the track geometry achieved by the improvement using the usual type of track maintenance have not reached the initial (at moment $t=0$ ) value of the quality index of track geometry in any case on the observed track sections in the performed analysis, i. e. never again has the original condition of the track quality been reached;

2) improvement values (I), reached by the usual type of track maintenance were, as a rule, greater on those track sections where the total track parameter quality was lower, whereas on those track sections where the total quality of track parameters was higher the very value of improvement (I) was lower at the same time;

3) apart from the two previous facts, the next one should be emphasised which refers to the deterioration rate of the track geometry quality before and after the carried out usual type of maintenance. The results have shown, namely, that the track sections with good total quality of track parameters after low improvement value (I), achieved by the usual type of track maintenance, the deterioration rate of the quality index of the track geometry that followed was of the same rate or a little faster in relation to the deterioration rate of the track geometry quality index before the performed maintenance. In case of track sections with poorer total quality of track parameters after high improvement value (I), achieved by usual type of maintenance, the deterioration rate of the quality index of the track geometry that followed was substantially faster compared to the deterioration rate of the quality index of track geometry before the performed maintenance. This only confirms the already set hypothesis that the interval between

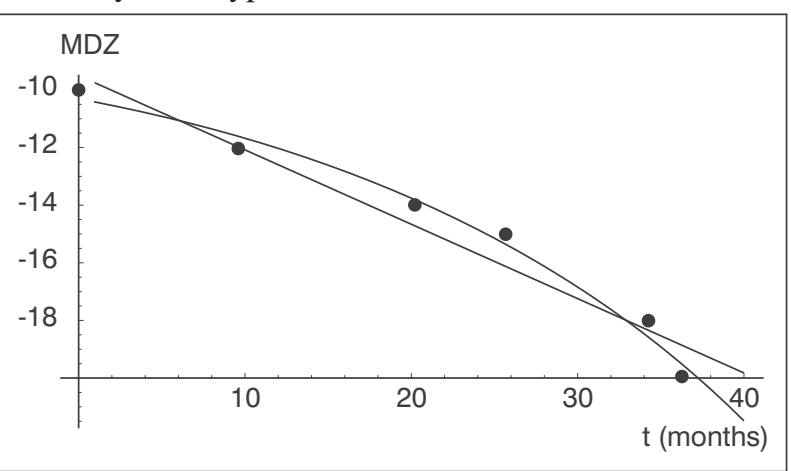

Figure 3 - One of the examples from the carried out research - approximation by linear and exponential function (type $2-e_{2}(X)=a-e^{b X+c}$ ), for track section on ATP-RG line track maintenance cycles is reduced by simultaneous increase in the traffic volume and by an increase in the number of track maintenance cycles for the observed period of time.

The results of the performed analyses have at the same time contributed to understanding of the hypothesis, set in the introductory part of this paper that the best possible conditions in track exploitation that can be achieved in a certain observed period of time are in direct correlation to the cycles of increasing the traffic volume and the cycles of performed track maintenance [8]. Without these calculations it is impossible to plan a high-quality, better to call it - sustainable schedule. An important element that directly affects the railway line capacity is a well planned schedule, since a designed schedule results in the railway route management activities. The basic purpose of the schedule is the realization of train operation according to precisely determined times and sequence. The train operation is at the same time coordinated with availability of the track infrastructure ${ }^{6}$. Thus, the subject of our research is not directly the very calculation of the railway line capacity but rather defining of the influence of inadequate track maintenance management (quantified by the reserve coefficient (p)) on the railway line capacity, which is precisely reflected in unnecessary introduction of slow runs and railway line closures.
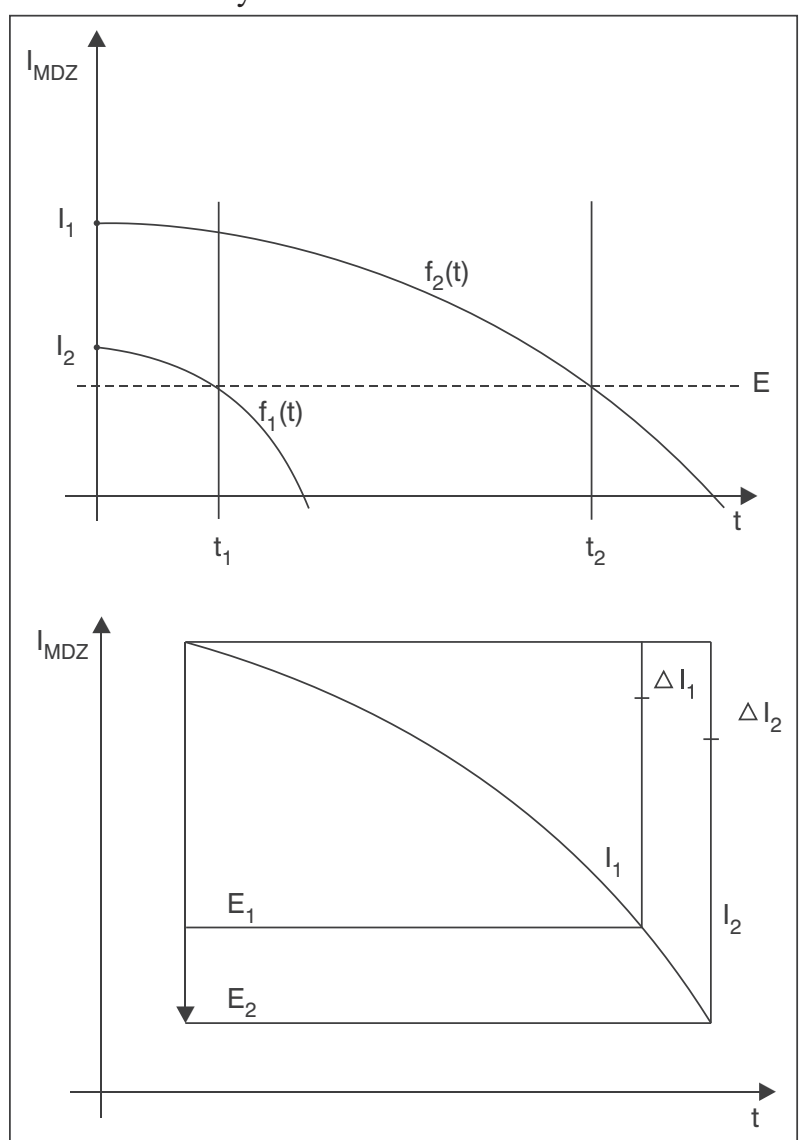

Figure 4 - Behaviour of track geometry quality improvement within the observed time period 


\section{PROPOSAL FOR THE IMPROVE- MENT OF TRACK GEOMETRY MAINTENANCE SYSTEM}

The Slovenian and Croatian railways have a scheduling computer system ROMAN (The ROute MANagement System). The Slovenian Railways can perform realistic simulations (in ROMAN module S software package) for the valid schedule that will refer precisely to the availability of railway capacities and the sustainability of the schedule. The information system ROMAN was developed for the needs of the railway operators, and is based on several years of experience in schedule design and on the cooperation of the railway operators and the companies from the railway sector.

These simulations are done in real environment on the pre-selected railway line, where the introduction of slow runs on single sections prolongs the travelling time by 1, 3 and 5 minutes per train. In this way the simulation is done and it shows the relation between the space and time components of the track infrastructure occupancy, by:

- displaying different inter-station distance occupancy levels and the computed railway line section;

- establishing relation between different delay values and the type of traffic conflicts;

- displaying the reduction in the interstation distance capacity and the computed railway line section, expressed in the number of trains that have been cancelled from the schedule.

For the presentation of simulation a number of different situations are selected, both on single track railway lines and on double track railway lines with combined traffic (passenger and freight) over a period of several hours. These simulations will serve in this case to determine the actual improvement in optimizing the availability of the track infrastructure capacities based on the previously presented theoretical considerations.

We have already emphasised, namely, that the traffic control activity consists of determining the possible number of railway routes on each track network railway line which are offered on the transportation market and of organizing and planning all the activities and tasks that refer to track maintenance. For the efficient and high-quality performance of traffic control, the rail routes management has to be done in a very systemic way that encompasses long-term planning, calculation and forecast of the track infrastructure capacity and the development of a sustainable (stable) schedule. Such an approach would result in a more efficient elimination of slow runs and reduction of the impact of track closure on their availability, thus providing much better realization of the schedule, i. e. insuring the contracted railway routes.

For the implementation of such a system ${ }^{8}$, the procedures and processes regarding track infrastructure management and maintenance are precisely predefined, including the levels of responsibility and the employees in charge of implementing this part of the technological transportation process. The proposal of the technological procedure conceived in this way is presented in Figure 5.

This subsystem would be used only in those emergencies when the elimination of slow runs is to prevent loss of a certain number of forecast and contracted rail routes. Its main aim is to calculate precisely the lost capacity in every concrete case and to provide a proposal of activities by means of which such a situation on the network would be avoided (this part is impossible without the results presented by the performed research in relation to the forecasts of the track geometry quality behaviour and estimate of its improvement).

As result of such an approach a special classification of standard irregularities on the track infrastructure and the procedures of maintenance, reconstruction and replacement, is made, whose potential effect has been quantified and as such included in a special class which will be proposed as a concrete procedure in a concrete case together with the period of time within which it has to be carried out (most urgent cases within a period of max. 3 days, urgent cases within 7 days and the rest within 4 weeks).

These cases include the defects and irregularities on the track equipment, which cause train running speed reduction or railway line closures such as: irregularities and defects on the open line tracks or on the main transit station track, irregularities and defects on turnouts or on the parts thereof.

The proposal of measures for the elimination of the observed and analyzed defects and irregularities is verified by the main manager in the traffic control activity in a special document (report) which is delivered urgently before the very intervention in the form of an order to the locally authorized track infrastructure maintenance manager who studies the order and if necessary supplements it or requests additional opinion. After being checked, the order is delivered to the track infrastructure maintenance service which is responsible for carrying it out well and on time.

For every potential introduction of slow run additional estimates regarding the quality of the available track capacity on individual rail network lines need to be made. These data are presented in the form of tables (Table 2) in which these estimates have been standardized for easier registering.

Traffic control activity compared to the infrastructure maintenance activity is responsible for the procedures of urgent elimination of slow runs and railway 


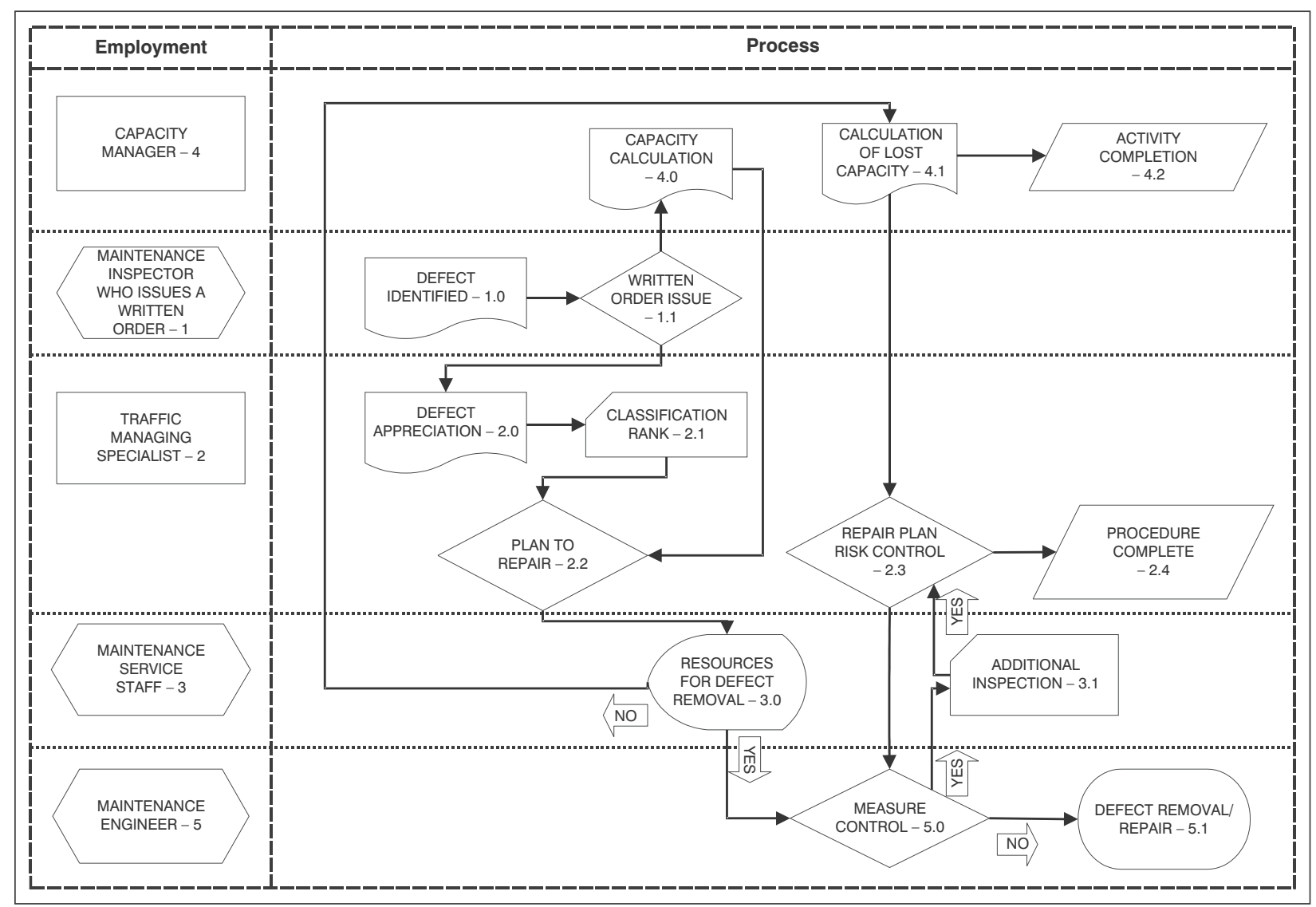

Figure 5 - Scheme of the technological process

Table 2 - The quality of the track infrastructure availability

\begin{tabular}{|c|c|c|c|c|c|}
\hline Type of defect $*$ & Line closure & Loss of routes & Rail line category** & Lost hours & Note \\
\hline A & YES & $<10 \%$ & M & $72 \mathrm{~h}$ & \\
\hline A & YES & $>10 \%$ & M & $72 \mathrm{~h}$ & max. lost hours $96 \mathrm{~h}$ \\
\hline A & NO & $<10 \%$ & M & $96 \mathrm{~h}$ & \\
\hline analogue & & & & & \\
\hline
\end{tabular}

line closures, according to the proposed diagram of technological processes of this activity.

The presented subsystem (light rail subsystem as part of the track infrastructure maintenance) is strictly hierarchically organized and presented only in that part in which it refers to the processes and activities of the employees involved in the activity of traffic control. Such a system is extremely feasible, i. e. efficient, and for its immediate implementation in practice it is necessary to partly modify the existing internal regulations and adequately train the experts in the traffic control activity. In such a new organizational and operative environment they would participate in a much better and more efficient way in making decisions both regarding emergency as well as mid-term and long-term measures, activities, and plans on the maintenance of the track infrastructure and its facilities.

\section{CONCLUSION}

The paper presents the procedures in the analysis and registering of the reasons for train delays, as well as simulation and calculation of the reduced railway line capacities. Consequently, a special subsystem in the traffic control activity has been proposed with the aim of rationalization of slow runs. This subsystem will make it possible for the rail infrastructure manager to provide much higher quality performance of the planned measures and activities in the field of track infrastructure and provision of services of adequate quality. Based on this subsystem it is possible to implement the track maintenance management system which would mean a significant improvement of the existing practice of maintaining 


\begin{tabular}{|c|c|c|}
\hline $\begin{array}{l}\text { Relation to the } \\
\text { proposed techno- } \\
\text { logical process } \\
\text { (Figure 5) }\end{array}$ & $\begin{array}{l}\text { Content of techno- } \\
\text { logical operations }\end{array}$ & Description of the procedures \\
\hline 2.0 & $\begin{array}{l}\text { Control/estimate of } \\
\text { irregularity, error }\end{array}$ & $\begin{array}{l}\text { In accordance with the brought decision on the introduction of slow runs or line } \\
\text { closure, the traffic control expert shall identify the reason for such procedure } \\
\text { and shall analyze and estimate the observed irregularity which is the cause. }\end{array}$ \\
\hline 2.1 & $\begin{array}{l}\text { Classification i.e. } \\
\text { categorization }\end{array}$ & $\begin{array}{l}\text { Based on the estimated irregularity, these are registered in accordance with the } \\
\text { valid standards and internal regulations, and included in the table of registered } \\
\text { irregularities on the track infrastructure (Table 1). A brief analysis of risks and } \\
\text { potential consequences of introducing slow runs is made (for the reason of fail- } \\
\text { ure to eliminate the cause of slow runs introduction). }\end{array}$ \\
\hline 2.2 & $\begin{array}{l}\text { Proposal of activi- } \\
\text { ties to eliminate } \\
\text { irregularities }\end{array}$ & $\begin{array}{l}\text { Represents the most important level of the decision-making process. In relation } \\
\text { to the previous step, a proposal is made for the elimination of the defined irregu- } \\
\text { larities, which has to be in compliance with the valid standards and table of regis- } \\
\text { tered irregularities on the track infrastructure (Table 1). The proposal in the } \\
\text { form of an order has to contain the necessary resources, including the necessary } \\
\text { material, employees and equipment. }\end{array}$ \\
\hline 2.3 & $\begin{array}{l}\text { Checking the } \\
\text { proposed order }\end{array}$ & $\begin{array}{l}\text { This second level in the decision-making process is necessary in case when due to } \\
\text { the lack of resources for the elimination of irregularities, the proposed activities } \\
\text { cannot be fully realized. It is then most important to eliminate at least partly the } \\
\text { irregularity, if its elimination cannot be postponed. A traffic control expert ob- } \\
\text { serves the pre-defined guidelines on short-term and mid-term measures for the } \\
\text { elimination of the risk against irregularity (the basis of the function of deteriora- } \\
\text { tion and improvement). }\end{array}$ \\
\hline 2.4 & $\begin{array}{l}\text { Procedure } \\
\text { completion }\end{array}$ & $\begin{array}{l}\text { After the analysis and development of the proposed activities the traffic control } \\
\text { expert deletes the track infrastructure irregularity from the database "Identified } \\
\text { irregularities" and enters it into the base "Defined measures" }\end{array}$ \\
\hline 4.0 & $\begin{array}{l}\text { Calculation of } \\
\text { available capacity }\end{array}$ & $\begin{array}{l}\text { In accordance with the determined and proposed decision, and based on the ob- } \\
\text { tained data on track infrastructure (speed reduction, track closures on open line } \\
\text { or at stations, irregularities of certain turnouts, etc.), the capacity manager starts } \\
\text { to calculate the new throughput capacity on the limiting headway. The results of } \\
\text { these calculations are then forwarded to the traffic control expert in order to } \\
\text { make the final measures and plans for the elimination of the defined irregulari- } \\
\text { ties. }\end{array}$ \\
\hline 4.1 & $\begin{array}{l}\text { Calculation of } \\
\text { reduced capacity }\end{array}$ & $\begin{array}{l}\text { After obtaining the information on resource availability, for elimination of irreg- } \\
\text { ularities on track infrastructure the capacity manager makes a new calculation of } \\
\text { the line throughput capacity i.e. the limiting headway. }\end{array}$ \\
\hline 4.2 & $\begin{array}{l}\text { Concluding } \\
\text { Activities }\end{array}$ & $\begin{array}{l}\text { The capacity manager stores all the calculations on the line capacity i.e. on the } \\
\text { current capacity of the limiting track headway in the database and thus con- } \\
\text { cludes the activities. }\end{array}$ \\
\hline
\end{tabular}

and reconstruction of the track quality. For the introduction of such a system the following steps need to be undertaken:

1. Structuring of a reliable and complete database of the track maintenance management system. Also, it is similarly important to include the database of the track maintenance management system into the process of performing railway operations both at the network level and at the level of individual projects.

2. The track maintenance management system should be able to present in a clear and high-quality manner the data for any aspect of the track exploitation.
3. The possibility has to be provided for studying on measuring sections, with markedly poor track exploitation conditions, with the aim of determining the root of the problem of the precisely such existing situation.

4. The models for forecasting of exploitation conditions on the tracks, economic estimates of alternative methods of performing maintenance and reconstruction, and the needs analysis for the precisely defined track infrastructure maintenance and reconstruction procedures have to be conceived and implemented.

The presented studies indicate a very important fact that the selection of any of the up to now devel- 
oped systems for the decision-making support regarding maintenance and reconstruction of the track quality has to recognize the specific features in the railway management considered in this sense. This will make the implementation process of such a system certainly in the function of optimizing the availability capacities of the track infrastructure.

If, regarding the discussed issues, such an approach in the traffic control activity should fail to be implemented, the consequence would be the introduction of unplanned slow runs and railway line closures, which is directly reflected on the total service quality in railway transportation.

\section{REFERENCES}

1. Directives EU 91/440/EGS, 12/2001/EU in 51/2004/EU

2. The quality index of track geometry MDZ also OEBB and $\mathrm{HŽ}$ are in use - see T. J. Mlinarić - Doctoral dissertation: "Dugoročna procjena kvalitete kolosiječne geometrije s ciljem identificiranja zahtjeva održavanja" (Long-term Assessment of Track Geometry Quality with the Aim of Identifying Maintenance Requirements), Faculty of Transport and Traffic Sciences and TU Graz, Zagreb, 2002

3. For the calculation of railway line capacity on the Croatian and Slovenian railways we use different methods, primarily the methodology according to UIC 405, and more recently the methodology according to UIC Directive 406.

4. In parallel graph all the trains run at the same speed on the same railway line sections. In non-parallel graph the trains are of different categories (fast, passenger, freight) and run at different speeds.

5. There are several methods for determining the coefficient of cancellations analytically.

6. This interdependence comes even more to the fore by the liberalization of the railway service market, where the railway route is in fact the basic product of the schedule and actually represents the offer of the railway infrastructure.

7. Exponential function which best describes the deterioration of the quality of the track geometry

$$
\mathrm{e}_{2}(\mathrm{X})=\mathrm{a}-\mathrm{e}^{\mathrm{bX}+\mathrm{c}}
$$

8. This is the subject of the study and research: "Strategija održavanja kolosiječne infrastrukture na magistralnim prugama HŽ-a” (Strategy of Maintaining Track Infrastructure on HŽ Main Railway Lines) carried out for the needs of $\mathrm{HŽ}-2004$

\section{Dr. sc. TOMISLAV JOSIP MLINARIĆ}

E-mail:mlinaric@fpz.hr

Sveučilište u Zagrebu, Fakultet prometnih znanosti

Vukelićeva 4, 10000 Zagreb, Republika Hrvatska

MIRAN PIRNAR, dipl. ing.

E-mail: miran.pirnar@slo-zeleznice.si

Slovenske železnice d.o.o.

Kolodvorska ul. 11, 1506 Ljubljana, Republic of Slovenia

\section{SAŽETAK}

\section{OPTIMIRANJE RASPOLOŽIVOSTI KOLOSIJEČNE INFRASTRUKTURE}

Neučinkovito izvršenje voznog reda koje se prvenstveno iskazuje u kašnjenjima vlakova, direktna je posljedica nedovoljnog raspoloživog kapaciteta postojeće željezničke infrastrukture koje generira niska razina uporabne kvalitete kolosiječne mreže u cjelini. Cilj istraživanja prezentiranog u ovom radu utvrdivanje je načina što kvalitetnijih intervencija upravitelja željezničke infrastrukture i djelatnosti vođenja prometa na smanjenje utjecaja laganih vožnji i zatvora pruga čime se osigurava dovoljan broj željezničkih trasa za potrebe korisnika i time kvalitetnije izvršenje voznog reda. U radu je dat konkretan prikaz obujma (veličine) laganih vožnji i zatvora pruga, izračun reduciranja razine željezničkih kapaciteta sa simulacijom i rezultat tog stanja na propusnu moć konkretne pruge te prijedlog modela organiziranja ekspertne skupine unutar djelatnosti vodenja prometa za što brže otklanjanje ovih negativnih pojava.

\section{KLJUČNE RIJEČI}

liberalizacija, iznajmljivanje trasa, propadanje kvalitete raspoloživost kolosijeka

\section{LITERATURE}

[1] M. Čičak, T. J. Mlinarić, B. Abramović: Method for Determining Throughput Capacity of Railway Lines Using Coefficients of Elimination, Promet - Traffic - Traffico, Vol. 16, 2, Zagreb, 2004, pp. 63 -69

[2] W. Ebersoehn: Ph. D. Dissertation: Substructure Influence on Track Maintenance Requirements, University of Massachusetts, Amherst, 1995

[3] W. Ebersoehn: Track maintenance management philosophy, 6-th International Heavy Haul Conference, pp. $784-796$

[4] T. J. Mlinarić: Ph. D. Dissertation: "Dugoročna procjena kvalitete kolosiječne geometrije s ciljem identificiranja zahtjeva održavanja", Fakultet prometnih znanosti i TU Graz, Zagreb, 2002

[5] K. Riessberger: Lecture: How to maintain track (Aspects of track maintenance), Brasil, July 1994

[6] K. Riessberger: Lecture: Track quality and ballast bed, Brazil, July, 1997

[7] K. Riessberger: Track geometry and economy - or - How good must a track be, ÖVG - Convention, Graz/Austria, 16-18 September 1997

[8] P. Veit: Habilitationsschrift: Rechenmodell zur wirtschaftlichen Bewertung von Strategien im Bereich Fahrweg, an der Technischen Universität Graz am Institut für Eisenbahn - und Verkehrswesen, Graz, March 1999 